\title{
ANALISIS MAKSIM PERBUALAN GRICE DALAM SOAL JAWAB TV3
}

\author{
Indirawati ZAHID \\ Akademi Pengajian Melayu \\ Universiti Malaya \\ 50603 Kuala Lumpur \\ indirawati@um.edu.my
}

Manuscript received 9 October 2018

Manuscript accepted 28 November 2018

\begin{abstract}
ABSTRAK
Maksim Perbualan (MP) diusulkan oleh Grice (1975) dalam usaha mengurangkan salah faham dalam komunikasi. MP mempunyai empat maksim, iaitu kualiti, kuantiti, hubungan dan cara. Diyakini sekiranya kesemua pemeran mematuhi MP, komunikasi akan berlangsung dengan lancar. Walau bagaimanapun, realitinya, tidak kesemua MP akan dipatuhi. Analisis telah dilakukan pada struktur isi rancangan Soal Jawab TV3 dengan mengaplikasikan MP dan membincangkan faktor kepatuhan dan ketidakpatuhan MP. Antara metod yang diaplikasikan adalah muat turun, transkripsi dan analisis teks. Pemeran komunikasi dalam rancangan ini melibatkan dua orang moderator (M) dan dua orang pemerhati ekonomi (PE). Dapatan analisis memperlihatkan keempat-empat MP dipatuhi oleh M manakala PE tidak patuh pada MP kuantiti dan cara. Kepatuhan MP oleh M dipengaruhi antaranya oleh prosedur penerbitan, kemahiran berbahasa dan pengalaman kerja. Kepatuhan MP oleh PE bertitik tolak daripada sifat rancangan yang yang mempunyai rujukan, iaitu maksim kualiti; manakala maksim hubungan ditandai dengan penggunaan kosa kata seperti inflasi, GST dan BRIM, iaitu tema ekonomi. Ketidakpatuhan MP oleh PE ialah pelanggaran maksim kuantiti dan cara yang bertujuan pemahaman audiens. Walaupun ketidakpatuhan berlaku, kelancaran komunikasi tidak terjejas. Dapatan ini sekali gus menolak pendapat Finch (2000).
\end{abstract}

Kata Kunci: maksim, Prinsip Kerjasama, kepatuhan, ketidakpatuhan, moderator

\section{GRICE'S CONVERSATIONAL MAXIMS IN SOAL JAWAB TV3}

\begin{abstract}
The Conversational Maxims (CM) was proposed by Grice (1975) in order to reduce misunderstandings in communication. The $C M$ has four maxims which are quality, quantity, relation and manner. It is believed that if all communicators observe the
\end{abstract}


$C M$, the communication will take place smoothly. However in reality, not all CM will be adhered to. Analysis was done on the body structure of the television programme, Soal Jawab TV3 by applying the CM, and the observance and nonobservance of CM. The programme was transcribed and analysed. The communicators involved were two moderators $(M)$ and two economic observers (EO). Findings show that four $C M$ were observed by $M$ while $C M$ of quantity and manner were not observed by $E O$. M's observations of the CM were influenced by publishing procedures, language skills and working experience. EO's observation of the quality maxim was derived from the references used in the programme while the observance of the relation maxim was based on the use of vocabularies such as inflation, GST and BRIM for economicthemed discussions. The EO's nonobservance of CM were flouting of the maxims of quantity and manner which referred to the occurrence of detailed description and prolix respectively. Despite the nonobservance, the smoothness of communication was not affected. This finding dismissed the opinion of Finch (2000).

Keywords: maxims, Cooperation Principle, observance, nonobservance, moderator

\section{Pengenalan}

Komunikasi berkesan berhubungan dengan kelancaran interaksi yang berlaku. Dalam kasus soal jawab di televisyen, keberkesanan komunikasi dititikberatkan baik oleh moderator mahupun oleh tetamu undangan. Moderator yang bagus akan meningkatkan keberkesanan sesi soal jawab melalui soalan praatur di antara ahli panel bagi memastikan mesej program akan kekal sebagaimana objektifnya (Meetings Imagined, 2018). Nguyen (2015) menyatakan "a good moderator is great at improvisation, knows a tremendous amount of the given subject and understands what it takes to avoid facilitating an audience slumber party". Penyataan ini hanya akan dapat dimanifestasikan apabila moderator merupakan individu yang berpengalaman dalam bidangnya. Sementara itu ahli panel yang bagus pula perlu memiliki pengetahuan berhubung peranan mereka dalam rancangan, mengetahui cara penyampaian maklumat yang berkesan, kesedaran kepentingan perkongsian maklumat, mendengar dan menghubungkan hujah ahli panel lain dan memastikan diri bertenaga bagi rancangan yang disertai (Nguyen, 2015).

Komunikasi merupakan proses dua hala di antara pengguna bahasa dan akan hanya dianggap berjaya apabila kesemua pemeran yang terlibat dalam komunikasi tersebut mempunyai kefahaman yang sama tentang apa yang dikomunikasikan (Team FME, 2013, hlm. 4). Hal ini melibatkan proses memahamkan pemeran. Proses ini tidak mudah untuk dilakukan kerana kebarangkalian untuk berlakunya salah faham itu wujud. Lanjutan itu, dalam usaha mengurangkan kesalahfahaman, Grice (1975) telah mengesyorkan Prinsip Kerjasama (PK) yang mempunyai sembilan komponen sebagai garis panduan semasa berkomunikasi. Sembilan komponen ini kemudiannya dikumpulkan menjadi empat kategori yang dinamakan maksim perbualan (MP). Menurut Finch (2000, hlm. 159), "Grice's principle assumes that people cooperate in the process of communication in order to reduce misunderstanding". Penyataan Finch ini jelas menunjukkan usaha yang dilakukan bagi mengurangkan kesalahfahaman semasa komunikasi. Dan ini disokong 
oleh Grundy (2008, hlm. 88) yang menyatakan pemeran mengaplikasi maksim Grice untuk mencapai komunikasi berkesan dan mengelakkan salah faham. Perkara yang sama juga dinyatakan oleh Okanda, Asada, Moriguchi dan Itakura (2015), iaitu memahami peraturan perbualan merupakan teras untuk kelancaran komunikasi dan peraturan perbualan yang dikongsi dalam masyarakat akan menyumbang pada situasi saling memahami semasa perbualan.

\section{Sorotan Literatur}

Menurut Fadhly (2012), kajian dalam bidang pragmatik mencakupi tiga aspek utama, iaitu lakuan bahasa, implikatur perbualan dan kesantunan. Kajian berhubung implikatur perbualan, berfokus pada pematuhan dan ketidakpatuhan pemeran pada MP yang diusulkan oleh Grice. Dalam memperlihatkan kepatuhan dan ketidakpatuhan MP pelbagai korpus digunakan antaranya sesi temuduga, filem, novel, komunikasi dan sebagainya. Antara kajian yang dilakukan ialah Ephratt (2011), Phosravizadeh dan Sadehvandi (2011), Fadhly (2012), Al-Saedi (2013), Bilal dan Naeem (2013), Chaipreukkul (2013), Hanifah (2013), Sobhani dan Saghebi (2014), Shuwei (2014), Tajabadi, Dowlatabadi dan Mehri (2014), Abari dan Lotfi (2015), Harared (2015), Seftika (2015), Samosir (2015), Fahmi (2016), Mohamad, Mohamed dan Mohamed (2017), Msuya dan Massanga (2017), Taghiyev (2017), Xioaqin (2017) dan Ayaserh dan Razali (2018).

Ephratt (2011) melakukan analisis bagi menentukan status kesenyapan verbal yang dikatakan sebagai ketidakpatuhan pada MP. Dapatan kajian ini menidakkan label yang diberikan oleh kebanyakan sarjana bahawa kesenyapan sebagai ketidakpatuhan MP sebaliknya memperlihatkan bahawa kesenyapan verbal ini berperanan aktif dalam komunikasi. Sementara itu, Phosravizadeh dan Sadehvandi (2011) menganalisis pelanggaran dan pencabulan maksim kuantiti atas dua watak utama filem Dinner for Schmucks. Dapatan memperlihatkan pencabulan maksim kuantiti berlaku atas sebab kelewahan, sirkumlokasi dan kebecokan. Pelanggaran maksim juga berlaku dalam kajian Fadhly (2012). Fadhly menganalisis tiga korpus teks temuduga Presiden Indonesia, Susilo Bambang Yudoyono (SBY) dan mendapati SBY melanggar keempat-empat MP dengan tujuan penjagaan muka, perlindungan diri, kesedaran, kesantunan, mendapatkan perhatian, kawalan maklumat, penghuraian dan kejahilan. Kajian ini juga mendapati MP tidak bersifat universal.

Kajian Al-Saedi (2013) dalam novel The Giver karya Lois Lowry memperlihatkan penulis novel ini pada kebanyakan masanya telah menjadikan watak-watak dalam novel tersebut tidak mematuhi MP atas tujuan menjana implikatur baru, menyembunyikan kebenaran, pembujukan dan menyakinkan pembaca dengan mesej yang ingin disampaikan oleh penulis. Hal yang sama berlaku dalam kajian Bilal dan Naeem (2013) yang menganalisis dialog Presiden Pakistan semasa sidang media. Dapatan memperlihatkan Presiden Pakistan telah melakukan ketidakpatuhan MP atas tujuan mencuci minda khalayak dalam cubaan untuk mendapatkan sokongan dan mengalih tumpuan daripada agenda politik yang sebenarnya. Sementara itu, Chaipreukkul (2013) pula mengkaji ketidakpatuhan MP yang berlaku dalam humor sitcom The Big Bang Theory. Dapatan memperlihatkan 
humor dimanifestasikan melalui ketidakpatuhan MP. Ketidakpatuhan yang dominan ialah pelanggaran diikuti dengan infringing, pencabulan dan pilihan keluar.

Hanifah (2013) menganalisis bahasa pengguna Facebook (FB) lelaki dan perempuan dengan fokus jenis maksim yang tidak dipatuhi dan bagaimana ketidakpatuhan ini berlaku. Kajian mendapati pengguna lelaki tidak patuh pada maksim hubungan manakala pengguna perempuan tidak mematuhi maksim kuantiti. Kedua-dua gender ini memperlihatkan kecenderungan melanggar maksim dengan berjenaka, memberikan lebih informasi atas tujuan untuk merasa lebih rapat dengan rakan selain sifat medium FB yang tidak mempunyai limit komunikasi apabila berinteraksi.

Sobhani dan Saghebi (2014) menganalisis pencabulan MP dalam data konsultasi psikologi Iranian. Objektif kajian ini adalah untuk memahami sikap tidak bekerjasama penutur dalam sesi konsultasi. Pencabulan MP dikatakan berlaku kerana konteks konsultasi psikologi yang berintipati kompleks sensitif dan terdapat pesakit yang sukar berkongsi maklumat - perasaan, idea, pendapat, masalah dan sebagainya.

Shuwei (2014) mengaplikasi pendekatan analisis wacana dalam mengkaji penggunaan MP hos rancangan bual bicara televisyen bahasa Cina. Temu bual melibatkan dua orang tetamu, iaitu masing-masingnya penutur natif bahasa Mandarin dan bahasa Inggeris. Dapatan memperlihatkan hos rancangan mematuhi MP dan sering kali meminta pengesahan dalam usaha memahami dan menyemak mesej tetamu undangan.

Sementara itu, Tajabadi, Dowlatabadi dan Mehri (2014), menganalisis MP dalam hujah pertikaian lisan dalam Majlis Penyelesaian Pertikaian Iran. Tiga rakaman mesyuarat Majlis dianalisis. Dapatan memperlihatkan dua kasus, iaitu kepatuhan dan ketidakpatuhan maksim. Kepatuhan maksim cara dan kualiti didapati kerap berlaku masing-masingnya atas alasan mengelakkan ketaksaan dan kebenaran. Sementara, pencabulan maksim paling kerap pada kuantiti dan hubungan kerana kesemulajadian komunikasi perundangan yang perlu jelas dan tidak taksa dengan mengemukakan maklumat yang lebih daripada yang sepatutnya selain kewujudan isu di luar topik perbincangan.

Harared (2015) memperlihatkan dua jenis ketidakpatuhan maksim, iaitu pelanggaran dan pencabulan maksim dalam filem Diary of a Wimpy Kid. Pelanggaran maksim berpunca daripada situasi hubungan di antara watak yang mempunyai hubungan yang rapat, iaitu adik-beradik dan kawan rapat. Hubungan rapat ini menjadikan mereka sudah saling memahami dan menjadi punca kepada ketidakpatuhan maksim berlaku. Pencabulan maksim berlaku apabila penutur mahu menyembunyikan sesuatu fakta, iaitu faktor matlamat perbualan sesuatu konteks.

Analisis etnografi dengan penerapan MP dalam interaksi tawar-menawar pembelian di sebuah pasar dilakukan oleh Samosir (2015). Dapatan memperlihatkan secara dominannya pematuhan MP hubungan dan cara dalam proses tawarmenawar. Pematuhan MP hubungan diperlihatkan melalui interaksi yang relevan dengan perkara yang dibicarakan, iaitu tema interaksi dalam jual-beli barangan. Pematuhan MP cara pula diperlihatkan melalui maklumat yang jelas, ringkas, teratur dan tenang. Pelanggaran MP kuantiti berlaku apabila juru jual memberikan informasi 
melebihi apa yang sepatutnya manakala pelanggaran kualiti diperlihatkan melalui informasi yang tidak jujur, tidak sesuai dengan fakta dan kenyataan dalam bertutur.

Kajian ketidakpatuhan MP ahli politik diteruskan oleh Seftika (2015). Analisis menggunakan korpus temu bual Barack Obama dengan ABC News dalam rancangan Good Morning America. Dapatan analisis menunjukkan terdapat lapan belas pelanggaran maksim mencakupi kuantiti, relevan dan cara. Pelanggaran maksim kuantiti dan cara didapati kerap berlaku dengan tujuan mengelakkan pemberian pandangan yang tepat.

Fahmi (2016) mengenal pasti maksim yang sering dicabuli dan faktor berlakunya pencabulan dalam perbualan seharian. Kajian ini memperlihatkan maksim yang sering dilanggar dalam percakapan seharian mahasiswa dan mahasiswi anggota EZC FPBS IKIP MATARAM. Dapatan memperlihatkan bahawa berlakunya pelanggaran maksim kuantiti sebanyak 30 kali, maksim kualiti sebanyak 20 kali, maksim cara sebanyak 10 kali, dan maksim hubungan sebanyak 5 kali. Umumnya keempat-empat MP dicabuli dengan faktor budaya dan jarak sosial merupakan faktor pencabulan berlaku.

Kajian maksim kuantiti dalam perbandingan teks bertulis penulis Iran dan penutur natif bahasa Inggeris dilakukan oleh Abari dan Lotfi (2015). Dapatan menunjukkan bahawa kedua-dua bangsa penulis ini telah melakukan ketidakpatuhan maksim, iaitu pencabulan maksim kuantiti dalam penulisan artikel bahasa Inggeris mereka. Walau bagaimanapun kekerapan pencabulan maksim didapati lebih tinggi dalam artikel yang ditulis oleh penulis Iran dalam teks bahasa Parsi.

Mohamad, Mohamed dan Mohamed (2017) menganalisis pencabulan dan pelanggaran MP yang dilakukan oleh pelajar Cina semasa proses pembentangan kerja kursus dalam bahasa Melayu. Dapatan memperlihatkan pencabulan dan pelanggaran MP sering berlaku masing-masingnya secara tidak sengaja dan sengaja. Kajian ini menyatakan bahawa pencabulan dan pelanggaran maksim ini tidak dapat dielakkan. Kesemua ini berpunca daripada kebolehan, keupayaan dan tahap penguasaan bahasa Melayu pelajar.

Msuya dan Massanga (2017) menganalisis kepatuhan MP oleh ahli politik Tanzania dalam satu temuramah di televisyen. Kajian berfokus pada maksim kualiti dan kuantiti. Dapatan memperlihatkan ketidakpatuhan berpunca daripada soalan yang berbentuk pelbagai dan soalan yang tidak patuh pada maksim. Antara bentuk soalan yang tidak patuh maksim termasuklah yang bersifat pelanggaran, pilihan keluar dan pertembungan maksim. Ketidakpatuhan ini berlaku bertujuan memperoleh kredibiliti sosial dan politik, mewujudkan kesantunan, mengelakkan ancaman muka dan membina imej positif.

Kajian Taghiyev (2017) tentang jenaka linguistik Inggeris berfokus pada pencabulan MP dan ketaksaan. Dapatan memperlihatkan pencabulan maksim kuantiti dan cara berlaku pada dua baris pertama jenaka lisan manakala pada dua baris kedua jenaka, pencabulan maksim hubungan dan cara berlaku. Dinyatakan pencabulan maksim kuantiti dan cara dilakukan secara senyap dan tidak disengajakan manakala pencabulan maksim hubungan berlaku akibat pelanggaran maksim. Dapatan kajian juga memperlihatkan ketaksaan boleh berlaku sama ada pada aras leksikal atau pun struktural. 
Xioaqin (2017) dalam kajian komunikasi ground staff syarikat penerbangan domestik China mendapati berlakunya strategi kelewahan komunikasi dalam perkhidmatan yang diberikan. Kelewahan komunikasi ini menunjukkan berlakunya pencabulan keempat-empat MP. Pencabulan MP antaranya bertujuan menjaga muka, mengelakkan konflik serta aduan dan mewujudkan keharmonian antara para penumpang.

Kajian terkini oleh Ayaserh dan Razali (2018) menganalisis ketidakpatuhan maksim ahli politik Syria - Presiden Syria, iaitu Bashar Al-Assad semasa temu bual dengan saluran ARD. Dapatan kajian memperlihatkan pelanggaran keempat-empat MP yang memberikan implikatur Al-Assad cuba mendapatkan sokongan daripada khalayak. Ketidakpatuhan ini juga berlaku bertitik tolak daripada implikatur bahawa maklumat yang diberikan tersebut akan berpihak kepada dirinya dan beliau akan terus mendapat sokongan daripada rakyat Syria.

Sehubungan itu, tinjauan literatur dalam kajian implikatur perbualan memperlihatkan penggunaan kepelbagaian korpus analisis dengan kecenderungan korpus yang digunakan ialah temu bual ahli politik dan filem. Dapatan yang diperoleh memperlihatkan dominasi ketidakpatuhan maksim. Kajian yang menggunakan korpus soal jawab ekonomi secara total belum ada. Yang ada hanya soal jawab yang juga menyelitkan perbincangan tentang ekonomi, iaitu kajian oleh Fadhly (2012), Bilal dan Naeem (2013), Masuya dan Massanga (2017) dan Ayaserh dan Razali (2018), iaitu apabila korpus tersebut melibatkan tokoh politik. Sementara itu, pengkaji tidak menemui kajian tentang implikatur perbualan dengan menggunakan rancangan televisyen atau radio berkaitan topik ekonomi. Sementara kajian yang menggunakan korpus media kebanyakannya mengunakan pendekatan analisis perbualan, iaitu satu aspek yang berbeza daripada kajian ini. Antara kajian yang yang mengaplikasi pendekatan analisis perbualan ialah Kong dan Su (2014), Carnel (2012), Schegloff (2007) dan Hutchby (2006). Pendekatan analisis perbualan cenderung membincangkan tentang strategi ambil giliran, tindakan dan urutan organisasi interaksi dalam rancangan.

\section{Permasalahan Kajian}

Kajian berintipati ekonomi per se belum dilakukan. Sehubungan itu kajian ini akan menggunakan korpus soal jawab berkaitan ekonomi bagi memperlihatkan kepatuhan dan ketidakpatuhan yang berlaku. Tujuan berlakunya kepatuhan dan ketidakpatuhan pasti memperlihatkan perbezaan kerana korpus yang berlainan digunakan. Lanjutan itu, dapatan yang akan diperoleh pastinya akan memperlengkap asbab ia berlaku.

\section{Objektif}

Kajian yang dilakukan ini mempunyai dua objektif, iaitu:

i. mengklasifikasi pematuhan dan ketidakpatuhan maksim perbualan oleh pemeran.

ii. membincangkan faktor berlakunya pematuhan dan ketidakpatuhan maksim perbualan oleh pemeran. 


\section{Metodologi}

Kajian yang dilakukan ini menggunakan data rancangan Soal Jawab TV3 yang dimuat naik di YouTube oleh DM Analytics pada 27 Oktober 2017. Rancangan ini disiarkan oleh TV3 dan berdurasi selama 1 jam. Tajuk rancangan Soal Jawab TV3 ini ialah PraBajet 2018. Rancangan ini mempunyai dua orang moderator dan dua orang tetamu undangan. Fokus analisis hanya pada struktur isi yang berdurasi 52 minit 28 saat.

Rancangan ini dipilih sebagai korpus kerana rancangan yang bertemakan bajet negara sering kali mendapat liputan dan menjadi satu siri rancangan yang wajib ada pada setiap tahun. la menjadi tarikan kepada khalayak yang mahu mengetahui pandangan pakar ekonomi yang diundang tentang hala tuju ekonomi negara serta jangkaan dan harapan mereka. Senario ini pula diperkukuh dengan situasi negara yang akan mengadakan piliharanraya ke-14 pada tahun 2018 - the mother of all elections (Tan, 2018; Chai, 2018) pada 9 Mei 2018 dan isu ekonomi negara menjadi antara topik utama yang dibicarakan.

Analisis dilakukan pada kesemua ujaran dalam struktur isi rancangan Soal Jawab TV3, mencakupi campur kod dan akronim dalam dialog kedua-dua orang moderator dan pemerhati ekonomi. Analisis tidak dilakukan pada komunikasi tak verbal, iaitu kinesik dan paralinguistik.

Kajian ini mengaplikasikan kaedah kualitatif yang mencakupi tujuh metod, iaitu kajian pustaka, muat turun, menonton, mengulang dengar serta mencatat bagi penyediaan transkripsi dan analisis teks. Analisis teks melibatkan proses penyisihan data mengikut konteks perbualan, iaitu dua orang moderator dan dua orang tetamu undangan. Analisis dilakukan dengan menggelompokkan data kepada konteks perbualan (KP) yang setiap satunya memperlihatkan koheren maklumat. KP akan disusun mengikut susunan kronologi data perbualan dan dilabelkan mengikut urutan nombor KP1, yang bermaksud Konteks Perbualan 1, KP2, merujuk kepada Konteks Perbualan 2 dan seterusnya. Terdapat 13 KP kesemuanya.

Dua orang moderator dalam rancangan dilabelkan sebagai M1 dan M2 manakala dua tetamu undangan yang dirujuk sebagai pemerhati ekonomi dilabelkan sebagai PE1 dan PE2. Dapatan analisis akan menggelompokkan kepatuhan dan ketidakpatuhan kedua-dua moderator dan pemerhati ekonomi sebagai satu paparan dapatan kerana dalam sesuatu KP berlakunya tumpang tindih komunikasi di antara para pemeran. Ini juga berkaitan dengan koheren maklumat dalam sesuatu KP.

Analisis pematuhan akan mencakupi keempat-empat MP manakala untuk ketidakpatuhan, infringing dan penggantungan maksim tidak diaplikasi. Ini kerana infringing tidak berlaku dalam kasus kedua-dua moderator dan pemerhati ekonomi kerana masing-masingnya merupakan wartawan berpengalaman dan pakar ekonomi yang biasa ditemu bual. Penggantungan maksim pula tidak diambil kira kerana analisis bertujuan memperlihatkan keberkesanan komunikasi melalui implikatur.

\section{Prinsip Kerjasama Grice (1975)}

Menurut Grice (1975) terdapat cara komunikasi yang diterima sebagai perlakuan standard. Perlakuan standard ini merujuk pada menghasilkan dan mendengar ujaran 
dengan anggapan umum bahawa komunikasi tersebut benar melalui pemilikan jumlah maklumat yang tertentu, relevan dan akan dapat mengungkapkan sesuatu yang dapat difahami (Davies, 2000, hlm. 2). Perlakuan ini dirujuk sebagai kerjasama dalam komunikasi, iaitu perbualan yang rasional dan dikawal oleh PK. PK dijangkakan berkuat kuasa apabila perbualan berlaku dengan saranan Grice kepada pemeran:

Make your conversational contribution such as is required, at the stage at which it occurs, by the accepted purpose or direction of the talk exchange in which you are engaged. (Grice, 1989, hlm. 26)

Menerusi PK, Grice (1975, hlm. 45) mengemukakan empat kategori MP, iaitu: i. maksim kuantiti (informatif) ii. maksim kualiti (kebenaran) iii. maksim hubungan (relevan) dan iv. maksim cara (kejelasan). PK diringkaskan seperti Jadual 1:

Jadual 1

Prinsip Kerjasama-Maksim perbualan

\begin{tabular}{|c|c|c|c|}
\hline $\begin{array}{l}\text { Maksim Kuantiti } \\
\text { (informatif) }\end{array}$ & $\begin{array}{l}\text { Maksim Kualiti } \\
\text { (kebenaran) }\end{array}$ & $\begin{array}{l}\text { Maksim Hubungan } \\
\text { (relevan) }\end{array}$ & $\begin{array}{l}\text { Maksim Cara } \\
\text { (kejelasan) }\end{array}$ \\
\hline $\begin{array}{ll}\text { a. } & \text { Pastikan } \\
\text { sumbangan } \\
\text { anda } \\
\text { bersifat } \\
\text { informatif } \\
\text { seperti } \\
\text { yang } \\
\text { diperlukan. } \\
\text { b. Jangan } \\
\text { jadikan } \\
\text { sumbangan } \\
\text { anda lebih } \\
\text { informatif } \\
\text { daripada } \\
\text { apa yang } \\
\text { diperlukan. }\end{array}$ & $\begin{array}{ll}\text { a. } & \text { Jangan } \\
& \text { bercakap } \\
& \text { sesuatu } \\
\text { yang } \\
\text { palsu } \\
\text { /tidak } \\
\text { benar. } \\
\text { b. Jangan } \\
\text { bercakap } \\
\text { sesuatu } \\
\text { yang } \\
\text { kurang } \\
\text { bukti. }\end{array}$ & $\begin{array}{ll}\text { a. } & \text { Pastikan } \\
& \text { berkaitan } \\
& \text { /relevan. }\end{array}$ & $\begin{aligned} \text { a. } & \text { Elakkan } \\
& \text { kekaburan. } \\
\text { b. } & \text { Elakkan } \\
& \text { ketaksaan. } \\
\text { c. } & \text { Ringkas } \\
& \text { (elakkan } \\
& \text { lewah). } \\
\text { d. } & \text { Pastikan } \\
& \text { teratur. }\end{aligned}$ \\
\hline
\end{tabular}

Walaupun Grice (1975) telah mengemukakan PK ini, beliau tetap mengakui bahawa akan berlaku juga ketidakpatuhan maksim semasa perbualan berlaku. Ketidakpatuhan ini mecakupi keempat-empat maksim yang dikemukakan dalam Jadual 1. Sehubungan itu dalam memerihalkan situasi ini, Grice telah menyenaraikan lima jenis ketidakpatuhan pada maksim seperti yang berikut:

1. Pelanggaran maksim berlaku dengan kesedaran atau pengetahuan penerima. Contohnya, Kuantan merupakan ibu negeri Johor - pelanggaran kualiti.

2. Pencabulan maksim berlaku apabila pemeran sememangnya berniat atau sengaja tidak mematuhi MP untuk menimbulkan salah faham atau dilakukan atas tujuan tertentu. Dalam kasus ini, penutur melakukan perkara ini dan 
penerima tidak mengetahuinya. Contohnya pembohongan nilai harga sehelai baju yang dibeli - pencabulan maksim kualiti.

3. Pilihan keluar berlaku apabila penutur memilih keluar daripada maksim dengan menggunakan frasa yang menyingkirkan atau mengurangkan kesan maksim dan memberikan isyarat kepada penerima. Contoh - kasus doktor yang tidak boleh memberikan maklumat pesakit pada audiens (kerahsiaan maklumat) akan menyatakan "saya tidak boleh berkongsi maklumat pesakit" pada soalan yang diajukan kepadanya.

4. Infringing the maxims dengan maksud penutur akan melakukan infringement berpunca daripada kurang pengetahuan atau kemahiran bertutur sesuatu bahasa, rasa cemas, keterujaan dan sebagainya yang menyebabkan gangguan kepada prestasi penutur.

5. Penggantungan maksim dengan maksud pemeran komunikasi menjangkakan ketidakperluan pematuhan pada maksim kerana ia tidak menghasilkan implikatur. Contohnya dalam pembacaan puisi wujudnya ketaksaan.

Situasi yang dijangkakan oleh Grice (1975) ini sememangnya akan berlaku. Penyataan ini disokong oleh Nieto $(2011, \mathrm{hlm}$. 36) bahawa people often fail to observe the maxims on many occasions. Dan kelima-lima jenis ketidakpatuhan maksim ini boleh berlaku pada mana-mana satu daripada empat MP dalam PK. Menurut Al-Saedi (2013) ketidakpatuhan maksim berlaku bukan disebabkan pemeran komunikasi itu tidak bagus tetapi ketidakpatuhan itu berlaku atas sebabsebab misalnya sesuatu perkara itu tidak dapat dikatakan secara langsung atau perlu disampaikan dengan cara yang berbeza. Al-Saedi memberikan antara sebab pencabulan maksim berlaku ialah bertujuan menjaga muka, memuaskan hati serta menghiburkan, mengelakkan rasa kekecewaan dan membujuk. Sementara itu, Darighgoftar dan Ghaffari (2012) berpendapat pencabulan dan pelanggaran maksim akan menyumbang lebih banyak maklumat berbanding sekiranya maksim dipatuhi.

\section{Dapatan}

Terdapat 13 KP bagi struktur isi Soal Jawab TV3 yang analisisnya akan dipaparkan dalam dua jadual utama yang berasingan, iaitu pertamanya Jadual Pematuhan dan Ketidakpatuhan MP dan keduanya Jadual Perincian Ketidakpatuhan MP. Huraian akan mengemukakan contoh bagi mewakili kasus yang dibincangkan dengan data analisis dielipsis bagi tujuan keringkasan. Jadual utama secara umumnya mempunyai lima kolum, kolum 1 - KP, kolum 2 - maksim kuantiti, kolum 3 - maksim kualiti dan kolum 4 - maksim hubungan dan kolum 5 - maksim cara. Analisis MP dilakukan dengan mengasingkan dapatan bagi moderator ( $M$ ) dan pemerhati ekonomi (PE). Jadual 2 memaparkan pematuhan dan ketidakpatuhan MP. 
Jadual 2

Pematuhan dan Ketidapatuhan MP

\begin{tabular}{|c|c|c|c|c|c|c|c|c|}
\hline \multirow[t]{2}{*}{$\begin{array}{c}\text { Konteks } \\
\text { Perbualan (KP) }\end{array}$} & \multicolumn{2}{|c|}{$\begin{array}{l}\text { Maksim } \\
\text { Kuantiti }\end{array}$} & \multicolumn{2}{|c|}{$\begin{array}{c}\text { Maksim } \\
\text { Kualiti }\end{array}$} & \multicolumn{2}{|c|}{$\begin{array}{c}\text { Maksim } \\
\text { Hubungan }\end{array}$} & \multicolumn{2}{|c|}{ Maksim Cara } \\
\hline & $M$ & $P E$ & $M$ & $\mathrm{PE}$ & $M$ & $P E$ & $M$ & $P E$ \\
\hline 1 & $\mathrm{~V}$ & $X$ & $\mathrm{~V}$ & 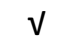 & $v$ & $v$ & $v$ & $X$ \\
\hline 2 & $\mathrm{~V}$ & $x$ & $\mathrm{~V}$ & V & V & V & V & $x$ \\
\hline 3 & V & $x$ & V & V & V & V & V & $x$ \\
\hline 4 & V & $x$ & V & V & V & V & V & $x$ \\
\hline 5 & V & $x$ & $v$ & $v$ & V & V & $v$ & $x$ \\
\hline 6 & V & $x$ & $v$ & $v$ & $v$ & V & $v$ & $x$ \\
\hline 7 & V & $x$ & V & V & $\sqrt{ }$ & V & V & $x$ \\
\hline 8 & V & $\varnothing$ & V & $\varnothing$ & V & $\varnothing$ & V & $\varnothing$ \\
\hline 9 & V & $x$ & V & V & 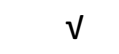 & $v$ & V & $x$ \\
\hline 10 & V & $x$ & V & V & 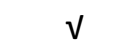 & V & V & $x$ \\
\hline 11 & V & $x$ & $\mathrm{~V}$ & $\mathrm{~V}$ & $\mathrm{~V}$ & V & v & $x$ \\
\hline 12 & V & $x$ & V & V & V & V & V & $x$ \\
\hline 13 & $V$ & $x$ & $V$ & $\sqrt{ }$ & $\mathrm{V}$ & V & $\mathrm{V}$ & $x$ \\
\hline Jumlah & 13 & 12 & 13 & 12 & 13 & 12 & 13 & 12 \\
\hline \multicolumn{9}{|l|}{ Petunjuk } \\
\hline M Moderator & $\begin{array}{r}\text { PE Pen } \\
\text { Ekono }\end{array}$ & & $\checkmark \mathrm{Apl}$ & & $\begin{array}{l}\text { X Tidak } \\
\text { Aplikasi }\end{array}$ & & $\varnothing$ Tiada A & \\
\hline
\end{tabular}

Jadual 2 memperlihatkan bahawa keempat-empat MP dipatuhi oleh moderator bagi kesemua KP. Walau bagaimanapun PE hanya mematuhi dua maksim, iaitu maksim kualiti dan hubungan. KP8 memperlihatkan tiada aplikasi kesemua MP oleh PE. Ini kerana KP8 hanya melibatkan perbualan di antara kedua-dua moderator sebelum sesi Soal Jawab TV3 berhenti untuk rehat. PE didapati melakukan pelanggaran maksim kuantiti dan cara.

Contoh komunikasi yang memperlihatkan pematuhan maksim dapat dilihat dalam Jadual 3 yang berikut.

Jadual 3

Kepatuhan Maksim

\begin{tabular}{|c|c|c|}
\hline KP & Pemeran & Dialog \\
\hline 1 & M1 & $\begin{array}{l}\text {... Saya nak tahu kalau ... petunjuk-petunjuk ekonomi semasa ... } \\
\text { kedudukan ekonomi ... dalam keadaan yang memberangsangkan ... } \\
\text { landasan yang baik. ... di mana ... ekonomi kita sekarang? Apakah } \\
\text { ia bergerak ... arah ... merasa selesa atau ... pandangan-pandangan } \\
\text {... menuju ke arah ... muflis. }\end{array}$ \\
\hline & PE2 & $\begin{array}{l}\text {... daripada segi kewangan negara ... ekonomi bertambah baik tapi } \\
\text { kewangan negara tidak memberangsangkan. ... sebab. Pertama, } \\
\text {...tengok hasil kutipan negara. ... Nombor dua, untuk menjana } \\
\text { ekonomi, ... ekonomi berbanding tahun lepas dengan tahun ni baik } \\
\text { lah, tapi dari segi kewangan agak tidak memberangsangkan }\end{array}$ \\
\hline 2 & PE2 & ... dijangkakan ekonomi kita akan naik tetapi pada kadar yang lebih \\
\hline
\end{tabular}


perlahan daripada tahun ini. Bank Dunia, IMF even Asian Development Bank ujurkan ...

\section{Petunjuk}

... elipsis

M1 Moderator 1

PE2 Pemerhati

Ekonomi 2

M1 dalam ujarannya telah mematuhi keempat-empat MP, maksim kuantiti berinformatif yang memadai; maksim kualiti - benar, iaitu ada rujukan - petunjukpetunjuk ekonomi; maksim hubungan- situasi semasa ekonomi negara dan maksim cara- ujaran yang ringkas, jelas (tidak kabur, tidak taksa) dan teratur. Hal yang sama pada ujaran PE2 ada rujukan - kewangan negara (kebenaran) - maksim kualiti; berinformatif dengan melakukan perbandingan - maksim kuantiti; dikaitkan dengan Bank Dunia, IMF, Asian Development Bank - maksim hubungan dan teratur dengan penomboran serta jelas - maksim cara.

Sementara itu, Jadual 4 memaparkan perincian kepatuhan dan ketidakpatuhan yang berlaku di antara pemeran.

Jadual 4

Perincian Ketidakpatuhan MP

\begin{tabular}{|c|c|c|c|c|c|c|c|c|c|c|c|c|c|c|c|c|c|c|c|c|c|c|c|c|}
\hline \multirow{3}{*}{$\begin{array}{l}K \\
P \\
1\end{array}$} & \multicolumn{6}{|c|}{ Maksim Kuantiti } & \multicolumn{6}{|c|}{ Maksim Kualiti } & \multicolumn{6}{|c|}{$\begin{array}{c}\text { Maksim } \\
\text { Hubungan }\end{array}$} & \multicolumn{6}{|c|}{ Maksim Cara } \\
\hline & \multicolumn{3}{|c|}{$M$} & \multicolumn{3}{|c|}{$P E$} & \multicolumn{3}{|c|}{$M$} & \multicolumn{3}{|c|}{$\mathrm{PE}$} & \multicolumn{3}{|c|}{$\mathrm{M}$} & \multicolumn{3}{|c|}{$\mathrm{PE}$} & \multicolumn{3}{|c|}{$M$} & \multicolumn{3}{|c|}{$\mathrm{PE}$} \\
\hline & $\mathrm{L}$ & $\mathrm{C}$ & K & L & $\mathrm{C}$ & K & $\mathrm{L}$ & $\mathrm{C}$ & $\mathrm{K}$ & L & $\mathrm{C}$ & K & $\mathrm{L}$ & $\mathrm{C}$ & K & L & $\mathrm{C}$ & $\mathrm{K}$ & $\mathrm{L}$ & $\mathrm{C}$ & K & L & $\mathrm{C}$ & K \\
\hline 2 & $\mathrm{x}$ & $x$ & $x$ & $\sqrt{ }$ & $x$ & $x$ & $X$ & $x$ & $X$ & $x$ & $x$ & $x$ & $x$ & $x$ & $x$ & $x$ & $x$ & $x$ & $x$ & $x$ & $x$ & V & $x$ & $x$ \\
\hline 3 & $x$ & $x$ & $x$ & $\sqrt{ }$ & $x$ & $x$ & $x$ & $x$ & $x$ & $x$ & $x$ & $x$ & $x$ & $x$ & $x$ & $x$ & $x$ & $x$ & $x$ & $x$ & $x$ & $\mathrm{v}$ & $x$ & $x$ \\
\hline 4 & $x$ & $x$ & $x$ & $\sqrt{ }$ & $x$ & $x$ & $x$ & $x$ & $x$ & $x$ & $x$ & $x$ & $x$ & $X$ & $x$ & $x$ & $X$ & $x$ & $x$ & $x$ & $x$ & $\mathrm{~V}$ & $X$ & $x$ \\
\hline 5 & $X$ & $X$ & $X$ & $\sqrt{ }$ & $x$ & $X$ & $X$ & $X$ & $X$ & $x$ & $X$ & $x$ & $x$ & $X$ & $X$ & $X$ & $x$ & $x$ & $x$ & $x$ & $x$ & $\mathrm{~V}$ & $X$ & $x$ \\
\hline 6 & $X$ & $X$ & $X$ & V & $x$ & $X$ & $X$ & $x$ & $x$ & $X$ & $X$ & $x$ & $x$ & $X$ & $x$ & $x$ & $x$ & $x$ & $x$ & $x$ & $X$ & $\mathrm{~V}$ & $X$ & $x$ \\
\hline 7 & $x$ & $x$ & $x$ & $\mathrm{~V}$ & $x$ & $x$ & $x$ & $x$ & $x$ & $x$ & $x$ & $X$ & $x$ & $x$ & $x$ & $x$ & $x$ & $x$ & $x$ & $x$ & $x$ & $\mathrm{~V}$ & $X$ & $x$ \\
\hline 8 & $x$ & $x$ & $x$ & $\varnothing$ & $\varnothing$ & $\varnothing$ & $\varnothing$ & $\varnothing$ & $\varnothing$ & $\varnothing$ & $\varnothing$ & $\varnothing$ & $\varnothing$ & $\varnothing$ & $\varnothing$ & $\varnothing$ & $\varnothing$ & $\varnothing$ & $\varnothing$ & $\varnothing$ & $\varnothing$ & $\varnothing$ & $\varnothing$ & $\varnothing$ \\
\hline 9 & $X$ & $X$ & $x$ & $\sqrt{ }$ & $X$ & $x$ & $X$ & $X$ & $X$ & $x$ & $X$ & $X$ & $X$ & $X$ & $x$ & $X$ & $x$ & $X$ & $X$ & $x$ & $X$ & $\mathrm{~V}$ & $X$ & $X$ \\
\hline $\begin{array}{l}1 \\
0\end{array}$ & $x$ & $x$ & $X$ & $\mathrm{~V}$ & $x$ & $X$ & $x$ & $x$ & $X$ & $X$ & $X$ & $x$ & $x$ & $x$ & $x$ & $X$ & $x$ & $x$ & $x$ & $x$ & $X$ & $\mathrm{~V}$ & $X$ & $x$ \\
\hline $\begin{array}{l}1 \\
1\end{array}$ & $X$ & $x$ & $x$ & $\mathrm{~V}$ & $X$ & $X$ & $X$ & $X$ & $X$ & $X$ & $X$ & $X$ & $X$ & $X$ & $X$ & $X$ & $x$ & $X$ & $x$ & $x$ & $X$ & $\mathrm{~V}$ & $X$ & $X$ \\
\hline $\begin{array}{l}1 \\
2\end{array}$ & $X$ & $X$ & $X$ & $\sqrt{ }$ & $X$ & $X$ & $X$ & $X$ & $X$ & $X$ & $X$ & $X$ & $X$ & $x$ & $x$ & $X$ & $X$ & $X$ & $X$ & $x$ & $X$ & $\mathrm{~V}$ & $X$ & $X$ \\
\hline $\begin{array}{l}1 \\
3\end{array}$ & $X$ & $x$ & $X$ & 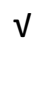 & $X$ & $X$ & $X$ & $X$ & $x$ & $X$ & $X$ & $X$ & $X$ & $X$ & $X$ & $X$ & $x$ & $X$ & $X$ & $X$ & $X$ & $\mathrm{~V}$ & $X$ & $X$ \\
\hline & & & & & & & & & & & & & & & & & & & & & & & & \\
\hline
\end{tabular}


Petunjuk

KP Konteks

M Moderator

PE Pemerhati

L Pelanggaran

Perbualan

Ekonomi

C Cabul

K Pilihan Keluar

$\sum$ Jumlah

X Tidak aplikasi

$\varnothing$ Tiada Aplikasi

$\checkmark$ Aplikasi

Jadual 4 memperlihatkan dapatan perincian ketidakpatuhan yang berlaku pada PE. Ketidakpatuhan, iaitu pelanggaran maksim kuantiti dan cara kecuali pada KP8, iaitu tiada aplikasi maksim kerana ketiadaan soal jawab yang berlaku.

Pelanggaran maksim kuantiti berlaku apabila PE dalam usaha memberikan jawapan kepada moderator telah menjelaskan maklumat melebihi detail yang diperlukan sekali gus didapati lewah. Lihat paparan contoh pelanggaran maksim kuantiti dalam Jadual 5 yang berikut:

Jadual 5

Pelanggaran Maksim Kuantiti

\begin{tabular}{lll}
\hline KP & PE & Dialog \\
\hline 5 & 1 & Memang kos sara hidup ni merupakan satu isu rakyat. ... . Aaa .. kita ada \\
& 3 elemen penting dalam kos sara hidup ni. Nombor 1, makan minumlah. \\
& .. . Yang ke-2 pengangkutan. Yang ke-3 perumahan. ... Dr. pun sebut \\
& tadi tentang ikan, tentang ayam. ... isu ikan ni sekarang. Isu ikan ni aaa .. \\
& isu ikan. Bila nelayan asing ... apa yang berlaku dekat harga ikan ini. Bila \\
& nelayan-nelayan asing ... dorang ambik kita punya ikan ... . The total \\
& value of hasil laut yang hilang ... lebih kurang $\mathbf{5}$ billion a year. 5 billion \\
& setahun. ... bila jadi macam tu, ikan kurang kan? Bila ikan kurang kita \\
& import. ... kita punya supplier tak cukup ... demand meningkat, harga \\
& akan meningkat. Harga meningkat ... . Yang ke-2, adanya orang tengah. \\
& $\ldots$ dia jual dekat peraih ni, dekat orang tengah ... .... orang tengah yang \\
& duduk kat tepi pantai ... memborong habis semua. ... beli ... harga \\
& rendah. ... ikan tak cukup dekat laut ... orang-orang the foreign nelayan \\
& asing dah ambik. ... orang tengah ... untung banyak ... sampai kat kita, \\
& the ... harga jadi tinggi. ... isu ayam ... ada sindiket tau. ... control the \\
& price of ayam ni. ... nelayan asing tadi dok pegi curi kita punya ikan apa \\
& semua tu .. .... inflation ... GST ... KPDNKK ...
\end{tabular}

$7 \quad 1 \quad$... RMK11 ... BRIM ... orang tua ni ... term sebagai warga emas ... lebih sedap sikitkan. ... dorang ni ada potential. ... saya ada ramai kawankawan yang warga emas. ... can still contribute. ... contoh ... Tan Sri KP ... Tan Sri Irwan, ... tap the knowledge, the skills, kemahiran ... in term of giving back to this people ... to contribute ... saya rasa ramai dorang nak contribute. ... Tapi tak diberi peluang. ... Orang tua-tua ni dia banyak, orang warga emas ni dia banyak petua. ... dia punya knowledge and then experience, pengalaman dia kepada to these people. ... elemen PR tu ... nak compromise, berhubung, interpersonal warga emas ni bukan satu liability ... an asset ... . 
Petunjuk

... elipsis

.. jeda mikro

Dalam KP5, ada tiga elemen yang dinyatakan oleh PE tetapi elemen pertama, iaitu isu ikan dihuraikan dengan detail. Antara isu ikan yang dibincangkan ialah perihal orang tengah - "duduk di tepi pantai", "beli semua ikan", "mereka beli harga murah", "untung tinggi"; nelayan asing - "curi ikan", "hasil laut hilang", "hasil tangkapan ikan nelayan tempatan menjadi kurang", "permintaan ikan yang tinggi", "ikan tidak cukup", "terpaksa import", "harga naik" dan sebagainya. Sementara isu ayam diberikan penyataan ringkas, iaitu harga yang dikawal oleh sindiket.

Sementara itu dua elemen yang berbaki, iaitu pengangkutan dan perumahan tidak dibincangkan dalam KP5. Ketiadaan perbincangan isu pengangkutan dan perumahan oleh PE dalam KP5 tidak dilabelkan sebagai ketidakpatuhan kerana jawapan yang diberikan dalam kasus ini telah berinformatif, benar, relevan dan jelas, iaitu mematuhi keempat-empat MP bagi menjawab pertanyaan moderator.

Dalam KP7, PE menghuraikan tentang warga emas yang dikatakan masih boleh menyumbang kepada pembangunan negara. PE mengemukakan "contoh Tan Sri Irwan", dan menghuraikan jenis sumbangan, iaitu "the knowledge", "the skills" dan "pengalaman". Kata-kata ini pula diulang beberapa kali. PE juga mengemukakan pandangannya sendiri tentang kesediaan dan jumlah warga emas yang mahu menyumbang kepada pembangunan negara. Penjelasan detail berlaku berkenaan kelebihan yang dimiliki oleh warga emas - "elemen perhubungan awam", "compromise", "berhubung" serta "interpersonal" dan seterusnya menyimpulkan bahawa mereka "bukan satu liability" tetapi "an asset". Penghuraian seperti ini memperlihatkan ketidakpatuhan PE. Namun ketidakpatuhan ini tidak menjejaskan intipati komunikasi bagi KP5 dan KP7 kerana maklumat yang dikemukakan ini sememang perlu dalam memahamkan audiens. Hal ini selari dengan dapatan Fadhly (2012) yang menyatakan maklumat detail melebihi keperluan ini akan menguntungkan audiens dan pihak wartawan.

Contoh ketidakpatuhan maksim cara dapat dilihat dalam Jadual 6 yang berikut:

Jadual 6

Pelanggaran Maksim Cara

\begin{tabular}{|c|c|c|}
\hline KP & PE & Dialog \\
\hline 4 & 2 & $\begin{array}{l}\text {... . Saya rasalah pada pendapat saya tak ada. Dia lebih bersifat } \\
\text { bertanggungjawab. I think it is responsible bajet dan saya rasa memang } \\
\text {.. memang banyak kehendak-kehendak penjawat awam. ... . Tapi saya } \\
\text { rasa kerajaan aaa .. saya rasa boleh fulfil. ... . Saya rasa kerajaan aaa .. tu } \\
\text { my opinion la pada pendapat saya tidak aaa .. keperluan tu .. kita still } \\
\text { tengok macam mana. }\end{array}$ \\
\hline 6 & 2 & $\begin{array}{l}\text { Saya rasa kalau boleh jangan .. jangan .. jangan .. jangan kurangkan lagi } \\
\text { peruntukan ... kita cut sana cut sini, macam mana kita nak perform kan. } \\
\text { So bermakna this perkara-perkara yang penting ni, basic requirement ni, } \\
\text { keperluan ni perlu ada. Dan jangan .. jangan potong la, jangan ada } \\
\text { bajet cut. ... TN50 }\end{array}$ \\
\hline
\end{tabular}


Petunjuk

... elipsis

.. jeda mikro

Ketidakpatuhan maksim cara dalam Jadual 6 dapat dibahagikan kepada dua kasus, iaitu pertamanya perulangan frasa yang bermaksud sinonim dan keduanya, perulangan frasa yang bermaksud penekanan maklumat. Kedua-dua kasus ini meyebabkan kelewahan yang tidak perlu berlaku berbanding dengan kelewahan dalam konteks pelanggaran maksim kuantiti - maklumat berlebihan yang dibincangkan sebelum ini.

Kasus pertama - sinonim, iaitu perulangan ujaran "saya rasalah" dan "pada pendapat saya"; "bertanggung jawab" dan "it is responsible"; "my opinion" dan "pada pendapat saya"; "requirement" dan "keperluan"; "jangan potong la" (elipsis kata bajet) dan "jangan ada bajet cut". Sementara itu bagi kasus kedua, perulangan - penekanan maklumat, kata "memang" yang berulang dua kali; ujaran "saya rasa", berulang tiga kali; kata "jangan", berulang empat serta tiga kali dalam dua ujaran yang berbeza dan kata "cut", berulang dua kali.

Contoh dalam Jadual 5 dan Jadual 6, memperlihatkan wujud ujaran "saya rasalah", "saya rasa", "my opinion", "pada pendapat saya" yang pada aras permukaan analisis memperlihatkan seperti berlakunya pelanggaran maksim kualiti, iaitu jangan bercakap sesuatu yang palsu/tidak benar dan jangan bercakap sesuatu yang kurang bukti. Walau bagaimanapun dalam kasus analisis, PE telah membuat tanggapan berasaskan rujukan, iaitu membuat pertimbangan wajar menggunakan rujukan seiring dengan kepakaran yang dimiliki, misalnya RMK11, kehendak penjawat awam, kedudukan fiskal dan sebagainya. Sehubungan itu tidak timbul isu pelanggaran mahupun pencabulan MP dalam kasus ini.

Contoh-contoh KP yang dikemukakan ini mewakili masing-masingnya kasus kepatuhan dan ketidakpatuhan MP yang berlaku dalam struktur isi. Dapatan juga memperlihatkan berlakunya korelasi di antara maksim kuantiti dan cara dalam kedua-dua kasus, iaitu apabila ujaran dikatakan lewah maka sifat ini juga tidak dikehendaki dalam maksim cara. Pelanggaran maksim cara ini tidak berhubungan dengan kasus ketaksaan dan kekaburan atas asas rancangan ini yang bersifat khusus dan khalayak sasarannya ialah orang yang mempunyai pengetahuan dalam bidang ekonomi dan memahami kosa kata ekonomi yang digunakan misalnya "demand", "supplier", "GST", "inflasi”, "TN50", "KPDNKK" dan sebagainya. Selanjutnya, faktor berlakunya kepatuhan dan ketidakpatuhan MP akan dihuraikan dalam Perbincangan.

\section{Perbincangan}

Pematuhan MP oleh moderator sememangnya sudah dijangkakan kerana tiga faktor utama, iaitu prosedur penerbitan rancangan, latar belakang moderator - jawatan yang disandang dan kemahiran berbahasa yang berhubungan dengan pengalaman yang dimiliki oleh moderator yang mengendalikan rancangan ini.

Faktor pertama, penerbitan sesebuah rancangan perlu melalui beberapa prosedur dan ini melibatkan perancangan yang rapi, iaitu sebelum keputusan penerbitan sesuatu rancangan tersebut dapat diterima. Setiap rancangan televisyen 
yang telah dikenal pasti penerbitannya akan melalui rangka kerja yang dinamakan papan cerita. Menurut Danesi (2009, hlm. 278), papan cerita ialah "blueprint for a film sequence or TV commercial, which is drawn to portray copy, dialogue, and action, with caption notes regarding filming, audio components, and script" yang antara lain bermaksud paparan urutan penggambaran dalam sesuatu penerbitan rancangan. Sementara itu, menurut Advanced Media Institute (2018), papan cerita mempunyai beberapa fungsi, iaitu membantu penentuan parameter cerita dalam sumber yang ditentukan dalam tempoh yang ditetapkan, menentukan aturan, fokus cerita dan mengenal pasti medium yang akan digunakan bagi setiap satu bahagian cerita tersebut. Penerbitan Soal Jawab TV3 pastinya melalui prosedur ini.

Faktor kedua, moderator dalam Soal Jawab TV3 bukan sahaja bertindak sebagai moderator dalam rancangan tetapi dalam masa yang sama merupakan wartawan penyiaran yang berperanan menyampaikan maklumat kepada khalayak. Menurut badan penyiaran tertua di dunia, iaitu British Broadcasting Corporation (BBC), wartawan penyiaran mempunyai spesifikasi tugas (Job Profile Broadcast Journalist, 2018), iaitu melakukan penyelidikan dengan pemantauan minimum, merentas kepelbagaian berita dan isu semasa, menulis skrip untuk TV, radio serta dalam talian dan sebagainya. Ini memperlihatkan bahawa wartawan penyiaran merupakan wartawan yang secara umumnya mempunyai pengalaman yang luas dalam pelbagai medium media dan mempunyai tugas agak mencabar. Dalam rancangan ini, wartawan penyiaran telah membuat penyelidikan tentang isu ekonomi yang akan dibincangkan dan latar belakang PE yang terlibat sesuai dengan etika kewartawanan yang perlu dipatuhi, iaitu antaranya berkewajiban berkhidmat kepada orang awam, bertugas secara telus dan bertanggung jawab (Plaisance, 2016).

Situasi ini diperkukuh dengan moderator merupakan wartawan penyiaran yang sudah bertugas agak lama dengan syarikat televisyen yang berkenaan. Dalam kasus ini, M1 merupakan seorang eksekutif kanan wartawan penyiaran sementara M2 pula merupakan seorang penerbit eksekutif. Jawatan yang disandang oleh kedua-duanya moderator ini memperlihatkan bahawa kedua-duanya sudah lama bertugas sebagai wartawan serta berpengalaman luas. Hal ini turut berhubungan dengan wibawa mereka sendiri yang telah diberikan tugas dan kepercayaan syarikat. Perrin and Dow (2016) menyatakan wartawan yang berpengalaman akan merancang teks mereka sebelum mula menulis, iaitu mencakupi matlamat penulisan, pelan, aliran dan sebagainya dalam tugas yang akan dilakukan. Dan ini jelas dibuktikan dengan organisasi maklumat yang disusun baik oleh kedua-dua moderator semasa mengendalikan rancangan.

Faktor ketiga, kemahiran berbahasa juga merupakan sesuatu yang dititikberatkan dalam kalangan wartawan. Aspek ini menjadi perkara yang dipentingkan sepertimana yang dinyatakan oleh Allen mantan eksekutif editor BBC Radio News (Little, 2015) bahawa sememangnya menjadi tugas wartawan untuk berkomunikasi dengan jelas dan efektif supaya berita yang disampaikan dapat difahami dengan mudah selain menyediakan kepada para penonton dan pendengar penggunaan bahasa yang bijak semasa berkomunikasi. Dalam kasus struktur isi Soal Jawab TV3 ini ternyata moderator telah menggunakan bahasa Melayu yang tidak menimbulkan kekaburan dan ketaksaan bahasa. Ini mematuhi maksim cara yang diusulkan oleh Grice (1975). 
Kepatuhan MP oleh PE mencakupi dua MP, iaitu kualiti dan hubungan. Kepatuhan MP kualiti bertitik tolak daripada maklumat yang dikongsikan dirujuk terlebih dahulu dengan dinyatakan sumbernya oleh PE - Bank Dunia, IMF, Asian Development Bank, RMK11 dan sebagainya. Ini merujuk pada nilai kebenaran.

Kepatuhan maksim hubungan dapat dilihat melalui penggunaan laras ekonomi yang ditandai oleh kosa kata seperti "inflasi", "GST", "BRIM", "demand", "supplier", "KPDNKK" dan sebagainya. Ini membuktikan isu yang dibincangkan ialah ekonomi. Penyataan ini selari dengan Beden dan Zahid (2017) yang menyatakan bahawa kerjasama akan wujud apabila berlakunya ketepatan dan kesesuaian penggunaan unsur-unsur bahasa dengan topik perbincangan.

Sementara itu, penggunaan akronim tidak menimbulkan gangguan semantik, iaitu gangguan linguistik seperti yang berlaku dalam kajian rancangan Mentor oleh Zahid dan Hashim (2018) kerana audiens Soal Jawab TV3 adalah audiens bersifat khusus kerana sifat rancangan itu sendiri. Dalam bidang komunikasi, "... noise, which is anything not intended by the informational source" (West \& Turner, 2000, hlm. 12).

Apabila kedua-dua maksim kualiti dan hubungan dipatuhi, maka tidak berlakunya pencabulan MP dalam rancangan ini kerana sifat informatifnya bertujuan perkongsian maklumat. Begitu juga tidak berlaku pilihan keluar MP kerana setiap satu soalan bersifat praatur kerana ada papan cerita yang disediakan lebih awal. Malah lazimnya ada sesi pra sebelum sesebuah rancangan dirakam (Fitzgerald, 2016).

Ketidakpatuhan MP yang dilakukan oleh PE hanya pelanggaran maksim kuantiti dan cara. PE ternyata bertindak mengemukakan contoh dan memberikan huraian yang detail dalam respons. Ketidakpatuhan ini tidak memudaratkan komunikasi yang berlangsung seperti yang dinyatakan oleh Fadhly (2012). Begitu juga pelanggaran maksim cara tidak menjadi isu besar dalam respons PE kerana perulangan yang berlaku berpunca daripada campur kod, bahasa Inggeris dan Melayu yang sinonim, iaitu terjemahan ujaran. Situasi ini juga menunjukkan kedwibahasaan PE dan audiens juga. Lazimnya, rancangan yang diterbitkan di Malaysia dan audiens sasarannya orang Malaysia, persoalan campur kod tidak menjadi isu dalam komunikasi. Ini kerana sebagai sebuah negara multietnik, pertembungan bahasa tidak dapat dielakkan. Sehubungan itu campur kod merupakan perkara biasa dalam kalangan penutur bagi sesebuah negara yang berciri sedemikain rupa (Albury, 2017).

\section{Kesimpulan}

Analisis Soal Jawab TV3 memperlihatkan kepatuhan keempat-empat MP oleh moderator manakala hanya maksim kualiti dan hubungan dipatuhi oleh PE. Kepatuhan MP oleh moderator sememangnya sudah dijangkakan kerana sifat scripted - papan cerita. Selain itu, soalan yang bersifat terbuka atau open-ended sering dikemukakan dalam soal jawab. Faedah penting soalan open-ended ialah "allow you to find more than you anticipate" (Farrell, 2016) kerana ia membuka ruang perolehan maklumat yang lebih. 
Kepatuhan maksim kualiti dan hubungan oleh PE juga sememangya telah dijangka kerana sifat perkongsian maklumat dan keilmiahan rancangan. Aplikasi kedua-dua maksim ini memperlihatkan korelasi. Dalam maksim kualiti, PE membuat rujukan sebelum membincang dan menghuraikan jawapan yang diberikan sesuai dengan kewibawaan kedua-duanya.

Pelanggaran maksim kuantiti dan cara tidak dapat dielakkan oleh PE kerana jawapan perlu diberikan penjelasan detail dan pengemukaan contoh yang relevan bagi tujuan pemahaman. Sifat soalan yang open-ended juga menjadi penyebab kepada senario ini. Walau bagaimanapun, tidak timbul isu ketaksaan dan kekaburan dalam maksim cara PE. Ternyata MP yang diusulkan oleh Grice (1975) tidak kesemuanya diaplikasikan oleh pemeran dan implikasinya pula tidak menimbulkan masalah. Sehubungan itu dapatan ini telah sekali gus menolak penyataan Finch (2000) sebelum ini.

\section{Rujukan}

Abari, A. F., \& Lotfi, A. R. (2015). On Grice's maxim of quantity: A comparative study of texts written by Iranian authors and native speakers of English. Research Journal of Recent Sciences, 4(1), 44-50.

Advanced Media Institute (2018). Storyboarding. Retrieved from https://multimedia. journalism.berkeley.edu/tutorials/starttofinish-storyboarding

Al-Saedi, H. T. J. (2013). A pragmatic study of the cooperative principle and Grice's maxims in Lois Lowry's The Giver (Unpublished Master of Arts Thesis), Southern Illinois University Carbondal.

Albury, N. H. (2017). Mother tongues and languaging in Malaysia: Critical linguistics under critical examination. Language in Society, 46(4), 1-23.

Ayasreh, A., \& Razali, R. (2018). The flouting of Grice's conversational maxim: Examples from Bashar Al-Assad's interview during the Arab Spring. Journal of Humanities and Social Science, 23(5), 43-47.

Beden, S., \& Zahid, I. (2017). Analisis konteks peristiwa bahasa melunas rindu: Aplikasi model Leech dan Grice. Akademika, 87(1), 17-34.

Bilal, H. A., \& Naeem, S. (2013). Probing into the dialogue of the president of Pakistan: Application of Grice's Maxims. International Journal of Linguistics, 5(4), 1-8.

Carnel, J. (2012). Aspects of talk show interaction: The Jonathan Ross Show and The Tonight Show with Jay Leno (Unpublished Master Dissertation), Ghent University.

Chai, J. (2018, April 11). Why GE14 is the mother of all elections. Retrieved from https://www.malaysiakini.com/columns/419308

Chaipreukkul, L. (2013). A study of non-observance of Grice's cooperative principle found in humor discourse: A case analysis of the situation comedy The Big Bang Theory. Humanities Journal, 20 (2), 223-249.

Danesi, M. (2009). Dictionary of media and communications. New York, NY: M.E. Sharpe. 
Darighgoftar, S., \& Ghaffari, F. (2012). Different Homeopathic characters violate cooperative principles differently. International Journal of Linguistics, 4, 266280.

Davies, B. (2000). Grice's cooperative principle: Getting the meaning across. Leeds Working Paper in Linguistics, 8, 1-26.

Ephratt, M. (2012). "We try harder"-Silence and Grice's cooperative principle, maxims and implicatures. Language \& Communication, 32, 62-79.

Fadhly, F. Z. (2012). Flouts of the cooperative principle maxims in SBY's presidential interviews. English Review: Journal of English Education, 1(1), 57-70.

Fahmi, R. (2016). An analysis of Grice's maxims violation in daily conversation. Journal of Languages and Language Teaching, 4(2), 91-97.

Farrell, S. (2016, May 22). Open-ended vs. closed-ended questions in user research. Retrieved from https://www.nngroup.com/articles/open-ended-questions/

Finch, G. (2000). Linguistic terms and concepts. London, England: Macmillan Press.

Fitzgerald, M. (2016, September 5). The TV \& Radio interview: A step-by-step guide to prepare for success. Retrieved from http://www.prnewsonline.com/tvradio-interview-step-step-guide-prepare-success

Grice. P. (1975). Logic and conversation. In P. Cole \& J. Morgan (Eds.), Syntax and semantics (Vol. 3) (pp. 41-58). New York, NY: New York Academic Press.

Grice, P. (1989). Studies in the ways of words. Cambridge, MA: Harvard University Press.

Grundy, P. (2008). Doing pragmatics. London, England: Hodder Education.

Hanifah, I.R. (2013). Non-observance of maxims in Facebook conversation. Passage, $1(2), 135-144$.

Harared, N. (2015). Non-observance of the maxims in Diary of a Wimpy Kid. Journal of English Language and Culture, 5(1), 43-53.

Hutchby, I. (2006). Media talk conversation analysis and the study of broadcasting. London, England: Open University Press.

Kong, R \& Su, T. (2014). An analysis of conversation structure in Ellen Show. Studies in Literature and Language, 9(2). 37-42.

Little, A. (2015, October 26) Principles of good writing. Retrieved from http://www.bbc. co.uk/academy/journalism/article.

Meetings Imagined (2018). 5 ways to make Q\&A sessions more effective. Retrieved from https://meetingsimagined.com/tips-trends/5-ways-make-qa-sessionsmore-effective

Mohamad, J. B., Mohamed, N., \& Mohamed, N. H. (2017). Tinjauan terhadap pencabulan dan pelanggaran maksim oleh pelajar Cina di dalam proses pembentangan kerja kursus bahasa Melayu. Journal of Global Business and Social Entrepreneurship, 3(7), 178-185.

Msuya, E. A., \& Massanga, M. (2017). The observance of Gricean conversational maxims by Tanzanian politicians in T.V. hosted interviews. English Literature and Language Review, 3(9), 82-90.

Nieto, A. R. (2011). The role of conversational maxims, Implicature and presupposition in the creation of humor: An analysis of Woody Allen's Anything Else. (Unpublished Master's Dissertation), University of Central Missouri. 
Nguyen, P. (2015, May 20). What makes a panel discussion a great talk show. Retrieved from https://www.linkedin.com/pulse/what-make-panel-discussiongreat-talk-sho w-phu-nguyen

Okanda, M., Asada, K., Moriguchi, Y., \& Itakura, S. (2015). Understanding violations of Gricean maxim in preschoolers and adults. Frontiers in Psychology, 6, 1-7.

Perrin, D., \& Dow, M. E., (2006). Journalists' language awareness: Inferences from writing strategies. Revista Alicantina de Estudios Ingleses, 19, 319-343.

Phosravizadeh, P., \& Sadehvandi, N. (2011). Some instances of violation and flouting of the maxim of quantity by the main characters (Barry \& Tim) in Dinner for Schmucks. Proceedings of the International Conference on Languages, Literature and Linguistics, Singapore.

Plaisance, P.L. (2016). Journalism Ethics. Oxford Research Encyclopedias. Retrieved from http://communication.oxfordre.com

Samosir, A. (2015). Penerapan prinsip kerjasama Grice dalam interaksi tawarmenawar (Analisis etnografi komunikasi di pasar Simpang Tigo, Pasaman Barat). Ranah. 4(2), 151-162.

Schegloff, E. A. (2007). Sequence organization in interaction: A primer in conversation analysis. Cambridge, England: Cambridge University Press.

Seftika. (2015). Flouts of the maxims in interview between Barrack Obama and Robin Roberts of ABC News" "Good Morning America". Jurnal SMART, 1(1), 1-9.

Sobhani, A., \& Saghebi, A. (2014). The violation of cooperative principles and four maxims in Iranian psychological consultation. Open Journal of Modern Linguistics. 4, 91-99.

Shuwei, Y. (2014). The use of Grice's cooperative principle in Chinese talk shows. (Unpublished Master's Dissertation), University of Malaya, Kuala Lumpur.

Soal Jawab TV3 Prabajet 2018 (2017, October, 27). Retrieved from https://www.youtube.com/watch?v=jisSMOhVTjE\&t=14s

Tan, J. (2018, April 8). Mother of all elections begins. The Star. Retrieved from https://www.thestar.com.my/opinion/columnists/analysis/2018/04/08/mot her- of-all-elections-begins-parliament-has-been-dissolved-the-actionwill-be-in-the- malay-heartla

Taghiyev, I. (2017). Violation of Grice's maxims and ambiguity in English linguistic jokes. IJASOS- International E-Journal of Advances in Social Sciences. 3(7), 284-288.

Tajabadi, A., Dowlatabadi, H., \& Mehric, E. (2014). Grice's cooperative maxims in oral arguments: The case of dispute settlement councils in Iran. ProcediaSocial and Behavioral Sciences, 98, 1859-1865.

Team FME. (2013). Effective Communications: Communication skill. Retrieved from http://www.free-management-ebooks.com

West, R., \& Turner, L.H. (2010). Introducing communication theory: Analysis and application. New York, NY: McGraw-Hill Higher Education.

Xiaoqin, L. (2017). Overcommunication strategies of violating Grice's cooperative principle in round service. English Language Teaching, 10(11), 162-172.

Zahid, I., \& Hashim, N (2018). Strategi dan struktur kesantunan Melayu dalam kritikan mentor rancangan realiti televisyen. GEMA Online Journal of Language Studies. 18(2), 134-153. 


\section{Penghargaan}

Nur Habibah Ahmad Suhimi, pelajar Akademi Pengajian Melayu (APM), Universiti Malaya (UM), Kuala Lumpur, Malaysia yang menyediakan transkripsi data. 